\title{
Cost Benefit Analysis of on-Board Desalinated Ballast Water from Oil and Natural Gas Trade as a Source of Water Supply for Abu Dhabi
}

\author{
Yanxiang Wang and I. Tsung Tsai
}

\begin{abstract}
This study investigates the cost and benefits associated with supplying Abu Dhabi with desalinated ballast water brought in with oil tankers and liquefied natural gas (LNG) vessels under different domestic water demand scenarios. Traditionally, the ballast water is discharged directly into the sea which has severely negative impact on the marine environment. The International Maritime Organization (IMO) is in the process of setting up a regulation requiring ballast water to be treated before it is discharged. To meet the requirement, desalinating the ballast water and supplying it to the local residents is one of the efficient ways. We analyze water trade of ballast water desalinated with waste heat generated from the propulsion of Oil Tanker and LNG vessels under different domestic water demand scenarios. Results show that in addition to the marine environmental benefit, ballast water trading will generate a cost saving in the range of \$771.5 million to $\$ 602.0$ million between 2012 and 2030 depending on the realized domestic demand for water in Abu Dhabi.
\end{abstract}

Index Terms-Ballast water management, desalination, oil and gas trade.

\section{INTRODUCTION}

Abu Dhabi highly depends on the desalination to treat the seawater due to lack of freshwater resources as a result of its harsh climatic environment. The economic boom of the emirate in the past decade has resulted in a substantial growth of fresh water demand. Currently, there are eight desalination plants in Abu Dhabi. To meet the growing water demand, more desalination plants need to be built. However, desalination plants are expensive to build and operate. Abu Dhabi is in the quest of identifying a new approach to increase water supply to meet the growing freshwater demand. Treated ballast water may be one of the solutions to explore given that it is environmental friendly, and is claimed to be cheaper than conventional desalination at some circumstances.

Abu Dhabi is one of the major oil exporting economies in the world. In 2009, the emirate exported 2.3 million barrels of oil per day (bpd). Oil is exported primarily from the port of Fujairah [1]. It has the fifth largest gas reserve in the world. Approximately $93 \%$ of the gas exporting from Abu Dhabi goes to Japan through liquefied natural gas (LNG) carriers with long term contracts [2]. The extensive oil and gas exporting activities introduce a large amount of ballast water

Manuscript received April 28, 2014; revised June 26, 2014. This work was supported in part by Masdar Institute of Science and Technology.

The authors are with Masdar Institute of Science and Technology, Abu Dhabi, UAE (e-mail: ywang@masdar.ac.ae, itsai@masdar.ac.ae). to the marine area of Abu Dhabi.

According to IMO estimates, 10 billion tons of ballast water is transported and discharged around the world every year. Fig. 1 shows how ballast water is used to maintain the stability of ships. For crude oil tankers and LNG vessels, most ballast water tanks are located in the bottom of the ships. In general, ballast water is uploaded to these ships at the oil and gas importing ports at the time when oil and natural gas are offloaded to the port. It balances the ship during the return route to oil and gas exporting countries, and is discharged to the sea at the destination ports.
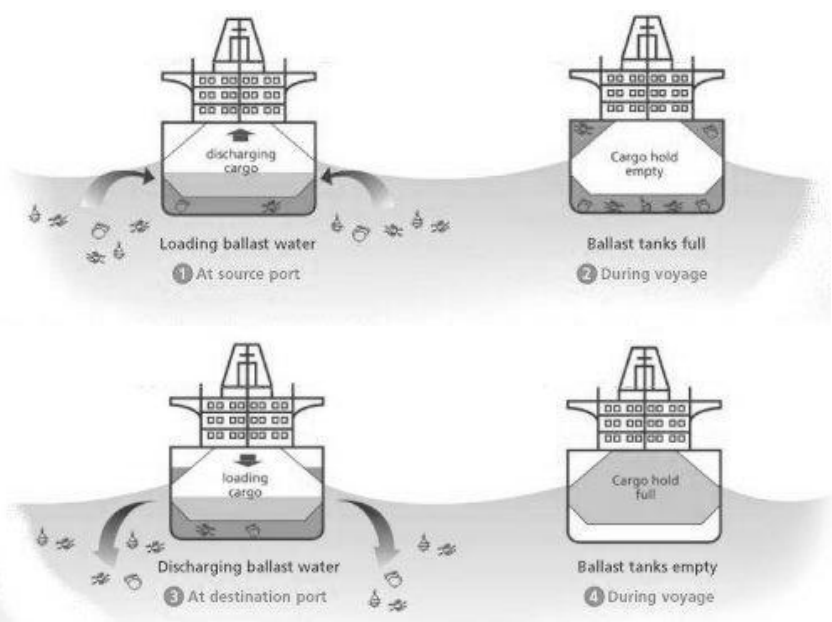

Fig. 1. Vessel ballast water tank [3].

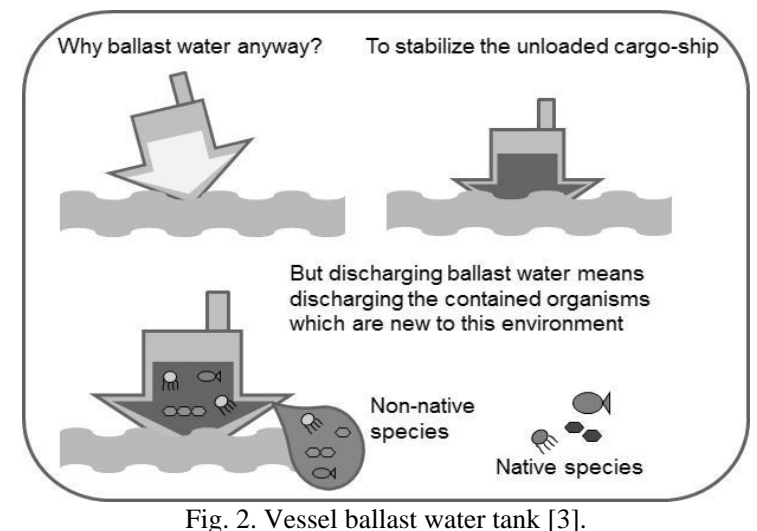

Ballast is normally untreated when it is discharged to the sea. As a result, non-native species that are uploaded along with the ballast water to the vessels will be discharged to the seas which affect the local marine environment (Fig. 2). Scientists estimate that as many as 3,000 alien species are transported by ships around the world every year. The alien species may become invading species when they impair the 
local ecosystem [3]. Furthermore, foreign organisms including bacteria, microbes, eggs, cysts and larvae have posted threat to local species in the host environment [4]-[9].

To mitigate the environmental impacts associated with the dumping of ballast water, IMO is in the process of implementing a mandatory regime of mid-ocean ballast water exchange [8], [9]. In the absence of ballast water exchange, the vessel needs to remove foreign organism from ballast water before discharging the ballast water into the sea. Technology wise, ballast water treatment methods using chemical, heat, filtration, or ultraviolet radiation technologies have been developed. In general, these technologies can be implemented either on-board or onshore [8]. This paper performs cost benefit analysis to identify the direct benefit of desalinating ballast water on-board using energy generated from the recovered waste heat from propulsion of the vessels under three different water demand forecasts scenarios.

The rest of this paper is organized as follows: Section II introduces different strategies and scenarios. Section III presents the model. Section IV shows the results. Section V concludes the analysis.

\section{DECISIONS AND SCENARIOS}

We identify the economic benefit of supplying Abu Dhabi with desalinated ballast water from oil and natural gas trade under various desalination strategies, water demand scenarios as well as domestic desalination capacity development schemes. This section first discusses two desalination strategies under consideration. Then it presents three water demand scenarios and two domestic desalination capacity development schemes.

\section{A. Desalination Strategy}

Our analysis comprises 2 water trading strategies to meet domestic water demand. In the first strategy, untreated ballast water is transferred onshore for desalination at the nearby plant to meet IMO requirements. In the second strategy, ballast water is desalinated on board the vessels during voyage using waste heat recovered from propulsion. Once reaching the port, this desalinated water is then transferred onshore for polishing at a standalone polishing plant before it is sold to the local market.

\section{B. Domestic Desalination Capacity Development Schemes}

We consider two domestic desalination capacity development schemes. In this first scheme, domestic fresh water shortage is met by new onshore desalination capacity regardless of the availability of desalinated ballast water. In the second scheme, domestic desalination capacity is added only when desalinated ballast water is insufficient to cover the water shortage. More specifically, the new onshore desalination capacity to add is set equal to the water shortage net of desalinated ballast water.

\section{Water Demand Scenarios}

Three scenarios have been considered, which are high water demand, most likely water demand and low water demand.

The baseline forecast produced by the Abu Dhabi Water and Electricity Company is used as the most likely scenario.

\section{THE MODEL}

We develop a simple model to calculate the difference between the direct costs and opportunity cost associated with the implementation of on-board ballast water desalination for Abu Dhabi. We break down the direct cost and opportunity cost into the following components:

A: Capex + Opex of treating ballast water to meet IMO requirements

S: Capex + Opex of desalinating ballast water on-board the ship

$\mathrm{K}$ : Opex of onshore desalination

Q: Capex + Opex of port infrastructure

M: Opex advantage of desalination with ballast water versus Gulf sea water

$\mathrm{M}$ is ignored in this analysis as there is no major cost advantages associated with MSF desalination, the dominating desalination technology deployed in the Middle East region. Given that the direct cost and opportunity cost of the 2 strategies vary with water trading strategy, port configuration, and onshore capacity development rule, we calculate the economic value added of each scenario using the equations as summarized in Table II:

TABLE I (A): WATER DEMAND SHORTAGE PRoJECTION ABU DHABI (2012-2030) (IN MiLlion M³) [10]

\begin{tabular}{|l|r|r|r|r|r|r|r|r|}
\hline Scenario & 2012 & 2013 & 2014 & 2015 & 2016 & 2017 & 2018 & 2019 \\
\hline High & -1.65 & -72.9 & -167 & -223 & -288 & -353 & -411 & -434 \\
\hline Most Likely & 58.0 & 0 & -66.3 & -125 & -179 & -228 & -263 & -459 \\
\hline Low & 198 & 119 & 68.0 & 11.6 & -19.8 & -56.4 & -94.5 & -134.3 \\
\hline
\end{tabular}

TABLE I (B): WATER DemAND SHORTAGE PROJECTION ABU DHABI (2012-2030) (IN MiLlion M³) [10]

\begin{tabular}{|c|c|c|c|c|c|c|c|c|c|c|}
\hline Scenario & 2021 & 2022 & 2023 & 2024 & 2025 & 2026 & 2027 & 2028 & 2029 & 2030 \\
\hline High & -518 & -586 & -641 & -671 & -679 & -697 & -749 & -765 & -772 & -802 \\
\hline Most Likely & -371 & -462 & -500 & -528 & -545 & -570 & -598 & -623 & -646 & -671 \\
\hline Low & -200 & -298 & -308 & -338 & -376 & -371 & -399 & -429 & -434 & -457 \\
\hline
\end{tabular}

TABLE II: ECONOMIC VALUE ADDED FOR EACH SCENARIO

\begin{tabular}{|c|c|c|c|}
\hline Strategy & Opportunity Cost & Direct Cost & Value Added \\
\hline $\mathrm{C}_{\text {None_B }} \mathrm{B}_{\text {Desalinate }}$ & $\mathrm{K}+\mathrm{A}$ & $\mathrm{S}+\mathrm{Q}$ & $\mathrm{K}+\mathrm{A}-\mathrm{S}-\mathrm{Q}$ \\
\hline $\mathrm{C}_{\text {New__ }} \mathrm{B}_{\text {Saline }}$ & $\mathrm{M}+\mathrm{A}$ & $\mathrm{Q}$ & $\mathrm{M}+\mathrm{A}-\mathrm{Q}$ \\
\hline
\end{tabular}

The economic value added is calculated in net present value (NPV) to provide a comparable result. For on-board desalination, we collect detailed data on the cost components of non-fuel versus fuel costs to identify the breakeven pump efficiency rate for feasible on-board ballast water desalination. The net present value for a desalination strategy 
is determined by

$$
\mathrm{NPV}=- \text { Capex }+\sum_{i=1}^{t}\left(\frac{\left[\mathrm{NF}_{i}+\mathrm{BW} \times \mathrm{PE} \times \mathrm{BP}_{i}\right] *(1+\mathrm{In})^{i}}{\mathrm{~PB} \times(1+r)^{i}}\right)
$$

where $\mathrm{NF}=$ No fuel opex $(\$ /$ year $) ; \mathrm{BW}=$ ballast water to treat $(\mathrm{m} 3 /$ year$) ; \mathrm{PE}=$ pump efficiency $(\mathrm{KWh} / \mathrm{m} 3) ; \mathrm{PB}=$ Power generation rate with bunker $(\mathrm{KWh} / \mathrm{t}) ; \mathrm{BP}=$ bunker fuel price $(\$ /$ ton$) ;$ In $=$ inflation rate $(\%)$; and $r=$ interest rate $(\%)$.

\section{DATA AND ASSUMPTIONS}

The water demand shortage data is acquired from the Abu Dhabi Water \& Electricity Company [10] shown in Table I. In Strategy I, all the water demand will be supplied by the desalination plant. So the desalination plants requirement is equal to the water demand shortage. In Strategy II, to meet the water demand shortage, first, we calculate the ballast water capacity potential by adding the oil and natural gas export volume together. The annual growth rates for the
Middle East oil and natural gas export are calculated using the projection of Middle East oil and natural gas export in BP Energy Outlook 2035 by British Petroleum (BP) [11]. The result for annual growth rates are $0.624 \%, 0.601 \%$ respectively for oil and natural gas export from 2012 to 2030. Since the United Arab Emirates (UAE) is one of the members of the Organization of the Petroleum Exporting Countries and Abu Dhabi is the major exporter of UAE, we assume the growth rates for oil and natural export in Abu Dhabi are the same as rest of the Middle East oil and gas exporters. Using $138,801,533.5 \mathrm{~m}^{3}$ as the oil export and $16,910,175 \mathrm{~m}^{3}$ as the natural gas export of Abu Dhabi in 2012 [12], the annual oil and natural gas export projections are calculated with Equation 2.

$$
E_{t}^{i}=E_{2012}^{i} \times g^{t-2012}
$$

where $E_{t}^{i}=$ the export of $i(i=$ oil, natural gas) in year $t . g=$ annual growth rate. The ballast water capacity is the sum of desalinated ballast water that can be derived from both oil and natural gas trades and is shown in Table III.

TABLE III (A): BALLAST WATER CAPACITY (2012-2030) (IN MILLION M ${ }^{3}$ )

\begin{tabular}{|l|l|l|l|l|l|l|l|l|l|l|l|}
\hline & 2012 & 2013 & 2014 & 2015 & 2016 & 2017 & 2018 & 2019 & 2020 & 2021 \\
\hline Ballast Water Capacity & 156 & 157 & 158 & 159 & 160 & 161 & 162 & 163 & 164 & 165 \\
\hline
\end{tabular}

TABLE III (B): BALLAST WATER CAPACITY (2012-2030) (IN MILLION M ${ }^{3}$ )

\begin{tabular}{|l|c|c|c|c|c|c|c|c|c|}
\hline & 2022 & 2023 & 2024 & 2025 & 2026 & 2027 & 2028 & 2029 & 2030 \\
\hline Ballast Water Capacity & 166 & 167 & 168 & 169 & 170 & 171 & 172 & 173 & 174 \\
\hline
\end{tabular}

\begin{tabular}{|c|c|c|}
\hline Cost Item & Capital Expenditure & Operating Expenditure \\
\hline Onshore Desalination (Conventional) & $\$ 920,876,346.12[8]$ & $\$ 0.26 / \mathrm{m} 3[9]$ \\
\hline On board Desalination & $\$ 1,544,812,093[13]$ & $\$ 0.36 / \mathrm{m3}[14]$ \\
\hline $\begin{array}{ccc}\text { Ballast Water } & \text { Treatment } & \text { System } \\
\text { (Conventional): } & & \\
\end{array}$ & $\$ 36,000,000[15]$ & $\$ 0.08 / \mathrm{m3}[15]$ \\
\hline Port Infrastructure: & $\begin{array}{l}P_{\text {Desal \& Polish Plant: }}: \$ 3,464,200 \\
P_{\text {Polish Khalifa Port }}: \$ 3,464,200[15]\end{array}$ & $\begin{array}{l}P_{\text {Desal \&Polish Plant }}: \$ 0.00166^{4} \\
P_{\text {Polish Port }}: \$ 0.00166^{4} \cdot[15]\end{array}$ \\
\hline \multicolumn{3}{|l|}{$\begin{array}{l}\text { Natural Gas Export Rate Equivalent: } 270 \text { bcf [4] } \\
\text { Vessel visits/year: } 12\end{array}$} \\
\hline $\begin{array}{l}\text { Time horizon: } 18 \text { years } \\
\text { Interest rate: } 8 \% \\
\text { Inflation rate: } 2 \% \\
\text { Project start date: } 2012\end{array}$ & & \\
\hline $\begin{array}{l}\text { Probability of carbon crediting is } 50 \%[15] \\
\text { Desalination technology benchmark: } \mathrm{MSF} \\
\text { Bunker fuel price }=\mathbf{\$ 6 0 0 / \text { ton } [ 1 5 ]} \\
\text { Pump electricity/fuel conversion rate }=\mathbf{5 0 0 0}\end{array}$ & $/ \operatorname{ton}[15]$ & \\
\hline $\begin{array}{l}\text { Port Facilities Assumptions: } \\
\text { Storage and Polishing capacity }=\$ 1,000,000 \\
\text { Pump }=\$ 10,000 / \text { pump } \\
\text { Pipeline }=\$ 200 / \mathrm{m} \\
\text { On-board desalination system }=\$ 4,500,000 /\end{array}$ & [15] & \\
\hline
\end{tabular}

TABLE IV: DATA AND ASSUMPTIONS

Second, we know the ballast water desalination system cannot cover all the water demand shortage. Thus the new desalination plants need to be built to meet the remaining demand of the water shortage. The capacity is calculated by deducting the ballast water capacity from the water shortage.

Data and assumptions used in the analysis are summarized in Table IV with corresponding reference. It is assumed that all water treatment and water production plants operate at maximum capacity.

Onshore Desalination capital expenditure is estimated with Capex for equivalent treatment capacity of 400,000,000 $\mathrm{m}^{3} /$ day. The operating expenditure is estimated with the 
average cost of desalination technologies used in the UAE, which include Multi-Stage Flash (MSF), Reverse Osmosis (RO) and Multi Effect Desalination (MED). Capex for ballast water treatment system is determined by the chosen treatment technology and is estimated to be $\$ 4,500,000 /$ ship while the on-board Opex is $\$ 0.36 / \mathrm{m}^{3}$ [16].

The required capacity for on-board desalination is determined by the minimum of the amount of ballast water on the oil and LNG tankers and Abu Dhabi water demand projection. We then estimate on-board desalination Capex with equivalent onshore capacity Capex by assuming the same technology is applied [15], [16]. Capex for port facility includes the costs of storage, pumps, and pipeline, whereas the Opex involves labour, pumps electricity consumption, insurance and maintenance which estimated just about $\$ 0.0077 \mathrm{~m} 3 / \mathrm{d}$ [16]. It is obvious that the above assumptions will have direct impacts on the analysis results. Similarly, uncertainties relevant to our analysis, which include future water demand, natural gas price and bunker fuel price may also affect the economic value added. Here we focus on the major uncertainties to provide benchmark information.

\section{REsults}

The total requirements of conventional desalination plant and ballast water desalination system under different strategies from year 2012 to year 2030 are listed in Table V. In strategy I, the desalinated water requirements are all from the conventional desalination plants, which are $9,298.77$ million $\mathrm{m}^{3}, 7,030.86$ million $\mathrm{m}^{3}$, and 4,081.58 million $\mathrm{m}^{3}$ respectively under different water demand forecast scenarios. In Strategy II, the desalinated water requirements for conventional desalination plants are $6,406.57$ million $\mathrm{m}^{3}$, 4,337.24 million $\mathrm{m}^{3}$, and 1,920.84 million $\mathrm{m}^{3}$. Meanwhile, they require 2,892.2 million $\mathrm{m}^{3}, 2,693.62$ million $\mathrm{m}^{3}$, and 2,160.74 million $\mathrm{m}^{3}$ desalinated water from the Ballast Water. The NPVs of each cubic meter water from onshore desalination plant under are $\$ 0.80775 / \mathrm{m}^{3}, \$ 0.80743 / \mathrm{m}^{3}$, and $\$ 0.80635 / \mathrm{m}^{3}$ respectively under three different water demand forecast scenarios. The NPVs of each cubic meter on-board ballast water desalination system are $\$ 0.54101 / \mathrm{m}^{3}$, $\$ 0.54094 / \mathrm{m}^{3}$, and $\$ 0.52772 / \mathrm{m}^{3}$ as shown in Table VI. The NPVs of each cubic meter water in Strategy I are more expensive than those in Strategy II which includes the Ballast Water desalination system. Table VII shows the NPVs of different strategies under different water demand forecast scenarios given by the multiplication of costs of each cubic meter water and total requirements. Implementing the Strategy II instead of Strategy I will save \$771.5 million, $\$ 717.8$ million, and $\$ 602.0$ million in three water demand forecast scenarios.

TABLE V: TOTAL REQUIREMENTS FOR CONVENTIONAL DESALINATION PLANT AND BALLAST WATER DESALINATION SYSTEM UNDER DIFFERENT STRATEGIES FOR 18 YEARS (IN MILLION M ${ }^{3}$ )

\begin{tabular}{|c|c|c|c|}
\hline \multirow{2}{*}{ Scenario } & Strategy I & \multicolumn{2}{|c|}{ Strategy II } \\
\cline { 2 - 4 } & Conventional & Conventional & Ballast Water \\
\hline High & 9298.77 & 6406.57 & 2892.2 \\
\hline Most Likely & 7030.86 & 4337.24 & 2693.62 \\
\hline Low & 4081.58 & 1920.84 & 2160.74 \\
\hline
\end{tabular}

TABLE VI: NPV OF EACH CUBIC METER WATER UNDER DIFFERENT STRATEGIES

\begin{tabular}{|l|c|c|}
\hline Scenario & Conventional & Ballast Water \\
\hline High & $\$ 0.80775 / \mathrm{m}^{3}$ & $\$ 0.54101 / \mathrm{m}^{3}$ \\
\hline Most Likely & $\$ 0.80743 / \mathrm{m}^{3}$ & $\$ 0.54094 / \mathrm{m}^{3}$ \\
\hline Low & $\$ 0.80635 / \mathrm{m}^{3}$ & $\$ 0.52772 / \mathrm{m}^{3}$ \\
\hline
\end{tabular}

TABLE VII: NPV OF DIFFERENT STRATEGIES UNDER DIFFERENT WATER DEMAND FORECAST SCENARIOS (IN MILLION)

\begin{tabular}{|l|l|l|l|}
\hline Scenario & Strategy I & Strategy II & $\begin{array}{l}\text { Money Saved } \\
\text { by using } \\
\text { Strategy II }\end{array}$ \\
\hline High & $\$ 7,511.1$ & $\$ 6,739.6$ & $\$ 771.5$ \\
\hline Most Likely & $\$ 5,676.9$ & $\$ 4,959.1$ & $\$ 717.8$ \\
\hline Low & $\$ 3,291.2$ & $\$ 2,689.1$ & $\$ 602.0$ \\
\hline
\end{tabular}

All calculations are done under the assumptions that Bunker fuel price $=\$ 600 /$ ton and Pump electricity/fuel conversion rate $=5000 \mathrm{kwh} / \mathrm{ton}$, the pump efficiency rate for feasible on-board ballast water desalination is $1.5 \mathrm{KWh} / \mathrm{m} 3$.

\section{CONCLUSION}

Our analysis shows that the implementation of the on-board ballast water desalination system generates a saving of 771.5 million dollars, 717.8 million dollars, and 602.0 million dollars respectively for three water demand scenarios. In sum, implementing the ballast water desalination system in Abu Dhabi is economically feasible.

In addition to economic benefits, on-board ballast water desalination will also contribute to environmental and health gains. The results of our analysis indicate that ballast water-based water trade may have great potential to contribute to cost efficient water supply in the Gulf Cooperation Council (GCC) countries. It may also contribute to the welfare of non-water sectors such as the tourism, fishing and shipping industries. Future studies may explore the environmental benefits from on-board desalinated ballast water as a source of water supply in the region.

\section{REFERENCES}

[1] IEA. (2011). Oil Market Report. [Online]. Available: http://omrpublic.iea.org/

[2] H. A. Kindi. (2010). Abu Dhabi's gas dilemma. [Online]. Available: http://www.adced.ae/imageCollection/EconomicReview/Issue/112520 1041611438906250.pdf

[3] Ballast Water Treatment Systems on Marine Vessels, MarineTech, 2013.

[4] S. Gollasch, "Removal of barriers to the effective implementation of ballast water control and management measures in developing countries," IMO MEPC Ballast Water Working Group, Short Version, 1998.

[5] D. M. Anderson et al., "The ecology and oceanography of harmful algal blooms," The American Society of Limnology and Oceanography, 1997.

[6] C. L. Hewitt and M. L. Campbell, "Mechanisms for the prevention of marine bioinvasions for better biosecurity," Marine Pollution Bulletin, vol. 55, no. 7, pp. 395-401, 2007.

[7] L. A. Drake, M. A. Doblin, and F. C. Dobbs, "Potential microbial bioinvasions via ships' ballast water, sediment, and biofilm," Marine Pollution Bulletin, vol. 55, no. 7, pp. 333-341, 2007.

[8] D. Boldor et al., "Design and implementation of a continuous microwave heating system for ballast water treatment," Environmental Science \& Technology, vol. 42, no. 11, pp. 4121-4127, 2008.

[9] N. N. Pereira and H. L. Brinati, "Onshore ballast water treatment: A viable option for major ports," Marine Pollution Bulletin, 2012.

[10] Statement of Future Capacity Requirements 2008-2030, Abu Dhabi Water and Electricity Company (ADWEC), p. 82, 2008. 
[11] BP Energy Outlook 2035, British Petroleum (BP), 2014.

[12] Statistical Year Book of Abu Dhabi, Statistics Centre - Abu Dhabi (SCAD), pp. 73-74, 2013.

[13] C. Gasson, C. Gonzalez-Manchon, and F. Alvarado-Revilla, “Desalination Markets 2010," Global Water Intelligence, 2010.

[14] R. Borsani and S. Rebagliati, "Fundamentals and costing of MSF desalination plants and comparison with other technologies," Desalination, vol. 182, no. 1, pp. 29-37, 2005.

[15] V. Gian, T. I. Tsung, H. Hector, and A. H. Talal, "Integration of Ballast water treatment and fresh water production for Abu Dhabi an economic assessment," in Proc. the Conference on Sustainable Business in Asia, Bangkok, 2012, pp. 203-209.

[16] T. Mezher et al., "Techno-economic assessment and environmental impacts of desalination technologies," Desalination, vol. 266, no. 1, pp. 263-273, 2011.

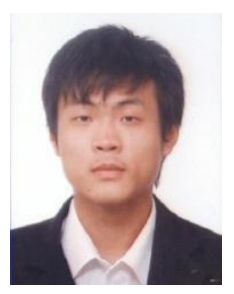

Yanxiang Wang was born in Shanghai, China, on Oct. 11,1989 . He is currently pursuing his master degree in Masdar Institute of Science and Technology in Abu Dhabi, United Arab Emirates (UAE). He is the assistant researcher in engineering systems and management program at Masdar Institute of Science and Technology.

His current research interests include the environmental policy analysis, computable general equilibrium modeling, and optimization. Previously, he studied the trade regulation of environmental goods in an oil producing economy and economic and environmental effects of electricity and water subsidy reduction in Abu Dhabi.

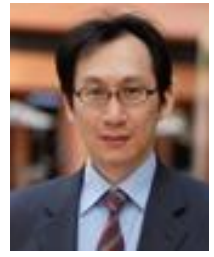

I. Tsung Tsai received a master and doctorate degrees in Massachusetts Institute of Technology (MIT). Now he is an assistant professor in engineering systems and management program in Masdar Institute of Science and Technology.

Prior to joining Masdar Institute faculty, Dr. I. Tsung Tsai served as a water strategy consultant for the Singapore government and was a visiting scholar to the Institute of Financial Research and Management, India in 2006. His research interests include carbon management, carbon finance, infrastructure policy and information economics. His current research estimates the effect of emission allowances on human health. Previously, he studied the implicit incentive mechanism embedded in financial contracts, and the effect of asymmetric information in the online auction markets. 